University of Nebraska - Lincoln

DigitalCommons@University of Nebraska - Lincoln

Sociology Department, Faculty Publications

Sociology, Department of

2020

\title{
Crime in Televised Presidential Campaign Ads: The Making of Visual Metaphor
}

Lisa A. Kort-Butler

University of Nebraska-Lincoln, lkortbutler2@unl.edu

Follow this and additional works at: https://digitalcommons.unl.edu/sociologyfacpub

Part of the Family, Life Course, and Society Commons, and the Social Psychology and Interaction Commons

Kort-Butler, Lisa A., "Crime in Televised Presidential Campaign Ads: The Making of Visual Metaphor" (2020). Sociology Department, Faculty Publications. 717.

https://digitalcommons.unl.edu/sociologyfacpub/717

This Article is brought to you for free and open access by the Sociology, Department of at DigitalCommons@University of Nebraska - Lincoln. It has been accepted for inclusion in Sociology Department, Faculty Publications by an authorized administrator of DigitalCommons@University of Nebraska - Lincoln. 


\title{
Crime in Televised Presidential Campaign Ads: The Making of Visual Metaphor
}

\author{
Lisa A. Kort-Butler \\ University of Nebraska-Lincoln, Lincoln, NE, USA \\ Correspondence - Lisa A. Kort-Butler Lkortbutler2@unl.edu University of Nebraska-Lincoln, \\ 711 Oldfather Hall, P.O. Box 880324, Lincoln, NE 68588-0324, USA
}

\begin{abstract}
In televised campaign advertisements, political rhetoric potently combines with visual metaphors. Drawing on a digital library of presidential campaign ads from 1952 to 2016, the qualitative media analysis scrutinized how crime rhetoric became visual metaphor. Crime images were positioned and manipulated alongside other content to craft a story about crime and the candidates. Across all ads, two tactics emerged: depicting crime as a problem akin to other social ills - a dark stain; and posing crime as the sinister side to an otherwise vibrant society - a lurking shadow. Candidates were branded as janitors and sheriffs who could rally against these foes.
\end{abstract}

\section{Introduction}

Much has been written about how campaign advertisements may influence the electorate in terms of voting patterns and attitudes about the political process (Kaid 2004). Crime has been part of this conversation (Petrocik, Benoit, and Hansen 2003; Sherr 1999). Attention has also been given to how politicians influence public opinion about crime and control issues, as well as the effect of public opinion on the politics of crime and punishment (Brown 2012; Frost 2010). The media are an engine by

Published in Deviant Behavior 2020, Vol. 41, No. 5, pp. 628-648.

DOI: $10.1080 / 01639625.2019 .1582972$

Copyright (C) 2019 Taylor \& Francis Group, LLC. Used by permission.

Submitted 29 October 2018; accepted 6 February 2019. 
which political messages about crime are filtered (Cavender 2004), but little criminological research has examined where the media and political influence directly meet - televised campaign advertisements.

Enns (2016) found political elites, including those involved in presidential campaigns, were responsive to public opinion polls that cited crime as the "most important" problem. The relationship between public sentiments and political policy are likely reciprocal, but Enns's work also revealed a concerted effort by the 1968 Nixon campaign (as an example) to capitalize on public concerns and use crime as a wedge issue (p. 8789). Lyons and Scheingold (2000) argued that shifts in criminal justice policy are driven by the electoral needs of politicians who massage punitive public sentiments, rather than solely by changing crime rates. Indeed, pronouncements by high-level politicians may lead to increased concern about crime, and the initiative power of presidents may yield policy changes at the federal and state levels (Jacobs and Helms 2001).

Presidents and presidential candidates often rely on symbolic rhetoric when discussing crime issues, intensifying the saliency of crime in order to increase their popularity and electability (Marion 1994; Marion and Oliver 2013). Tone matters, as political appeals to a fearful, fretting public further heightens the salience of crime in the public imagination (Zimring and Johnson 2006). Coding also matters. When politicians could no longer openly exploit racist sentiments, crime became a code word for Black (Tonry 2009). The "other" became the "criminal other," and support for law-and order became justification for this coded racial animus (Unnever and Cullen 2010).

Televised campaign ads ostensibly serve to showcase candidates' personalities as well as their policy positions (Franz et al. 2007), using frames that take advantage of the public's existing beliefs and values (Ramirez 2013). Through various techniques, ads craft both the candidate's image and a caricature of the opposition. They also communicate, to varying extents, a vision of the nation and world: (re)imagining the past; portraying the present; and projecting the future. In doing so, ads are a platform to turn politicians' symbolic rhetoric about crime into something more visual and potentially more visceral.

The overarching purpose of this project was to discover how the crime metaphors frequently used in political rhetoric were visualized in campaign ads. Visual criminology, "the study of ways in which all things visual interact with crime and criminal justice, inventing and shaping one another" (Rafter 2014:129), provided the lens through which I 
analyzed presidential campaign TV ads from 1952 to 2016. As the project unfolded, the manipulation of images, text, and sounds became the key to unveiling how crime rhetoric became visual metaphors, as well as the nature of those metaphors for the crafting a story of crime to advance a candidate's "brand."

\section{Politics and the crime metaphor}

Starting at least as early as the Hoover presidency, crime has been a feature of presidential politics (Marion and Farmer 2003). Simon (2007) described the ascendency of the crime metaphor in American politics, which fitfully started during the Goldwater-Johnson campaign in 1964, and took hold as the Johnson administration rolled out efforts at criminal justice reform. President Johnson's recasting of the war on crime drew heavily on metaphors that have come to pervade the politics of crime (Simon 2001). Johnson emphasized how crime undermined our Great Society, and in signing the Safe Streets Act, he hoped to "lift the stain of crime and the shadow of fear from the streets of our communities" (cited in Simon 2001:1056). These metaphors were rhetorically tied to specific stage sets: local neighborhoods and private spaces, which required protection, and public spaces, like the city street, which required reclamation. Victims - at least certain victims - were cast in the role of idealized citizens. Police was transformed from peace officers to soldiers. Legislators were poised as pugilists. Over the next few years, "crime" became an important framing tool to understand the shifting social landscape, one on which the 1968 Nixon campaign capitalized with the socalled Southern Strategy. Crime and civil unrest became stand-ins for the racial tensions of the era. With the 1968 campaign and the following Nixon years, the crime metaphor became entrenched as a powerful political weapon (Hagan 2010).

Indeed, research on mediated images of crime demonstrates how presentations of crime and control, whether in news, fiction, or non-fiction, generally conform to the dominant ideology of crime and justice that emerged in the U.S. in the latter half of the twentieth Century (Cavender 2004; Surette 2015). Alongside such depictions, politicians engage in crime control theater, responding to crime in ways that "generate the appearance, but not the fact, of crime control." (Griffin and Miller 2008:160). For example, three strikes sentencing reforms were designed 
to demonstrate something was being done about crime; in fact, such reforms were framed to the public as more radical than they were in practice (Jones and Newburn 2006). Reactionary, ill-informed, and impractical policies, gilded with symbolic crime rhetoric, are exhibitions of politicians taking action to protect public safety, even if those policies ultimately fall short (Yelderman et al. 2018).

Theatrical efforts offer no moral ambiguities, focusing on the dichotomy of villains and innocent victims. Policy actions in this vein also appeal to American mythic narratives that intensify a policy's theatrical potency (Griffin and Miller 2008:167): raising a posse to root out the bad guys, relying on technological dominance to track them, and so forth. Such theater impacts the public. In a series of studies, alternating terms like beast/virus to describe crime and warrior/guardians to describe police influenced how people responded to policy-related questions (Thibodeau and Boroditsky 2011; Thibodeau et al. 2017). When an action or policy is publicized - in signing ceremonies, speeches, and ads it signals an official commitment to public safety and morality.

\section{Campaign ads: envisioning the brand}

Parallel to the development of the crime metaphor and its use as political theater arose television as an effective means by which politicians could broadcast their messages (Barnhurst and Quinn 2012). Televised campaign advertisements are designed to inform voters about a candidate's stand on the issues and to communicate an "image" (Franz et al. 2007), laying out a political agenda and a schema of the candidate's personality characteristics (Johnston and Kaid 2002). Indeed, modern politics has become a battle of images, perhaps even eclipsing messages, such that branding a candidate is seen as central for gaining popularity and connecting to voters (Nielsen 2017; Scammell 2015). The metaphorical rhetoric employed by candidates in their stump speeches and press appearances provides almost ready-made visualizations to promote the brand.

The verbal and nonverbal elements of political ads, alongside other video techniques, give campaigns more control of the candidate's brand (Barnhurst and Quinn 2012). The brand includes the usual performance indicators, such as the candidate's agenda, accomplishments, and desirable attributes (e.g., leadership, trustworthiness). But the brand must 
also differentiate itself, and here cultural, social, and psychological cues play a primary role (Scammell 2015). Differentiators draw on symbolic imagery and rhetoric. For example, in reviewing campaign ads from 1952-1996, Sherr (1999) found that children were symbolically used to represent vulnerability on the one hand and amorality on the other, as stand-ins for an idyllic national past and a prosperous national future. Such symbols served to portray (i.e., brand) the candidate as protector, moral leader, and guide into a new era.

Research on presidential advertising suggests that although voters do not learn about issues from ads alone, they are persuaded toward candidates whose ads craft, for example, likeability (Huber and Arceneaux 2007). The use of imagery and music in ads, designed to cue emotional states like enthusiasm and fear, also affects voters' preferences. Technological distortions to the images themselves influence how people perceive candidates (Kaid 1997). Brader (2005) found that when positive ad frames were paired with cues for enthusiasm (e.g., uplifting music, colorful pictures of children), viewers' prior preferences for a candidate were reinforced. When negative ad frames were paired for cues for fear (e.g., discordant music, grainy pictures of violence), they were effective in persuading viewers based on their negative assessments of how candidates would handle the issues raised. Televised campaign ads, in effect, layer both the issues of the campaign and the image of the candidate with visual and aural cues intended to shape viewers' perceptions and preferences in ways more palpable than a typical stump speech.

Campaigns ads are fertile ground for sowing and visualizing crime metaphors as a way to brand a candidate. In this sense, "crime" becomes a political mascot. In advertising, mascots are designed to cue an emotional response by suppressing more realistic details, exaggerating characteristics meant to hit social psychological cues (e.g., large doe eyes for cuteness), and juxtaposing the mascot with other images (e.g., a cute mascot with an ugly image) (Cerulo 2016). As "organizational totems," mascots engage consumers and act as rallying point for the organization's identity among group members (Cayla 2013). Mascots also personify a storyline (Patterson, Khogeer, and Hodgson 2013), while an accompanying text or script breathes meaning into an otherwise anthropomorphic character. Likewise, campaigns ads serve to embody political rhetoric, potentially transforming crime metaphors into totems designed to support the candidate's brand. 


\section{Current focus}

Presidential campaigns exist in a specific social-historical context, which frames the issues that come to dominate campaigns. Crime, drug use, and deviance may be more or less politicized across time. When raised as salient policy topics or as social problems, however, they are tools for agenda-setting and campaign sloganeering (Zimring and Johnson 2006). In the symbolic rhetoric of political campaigns, the crime metaphor is deployed as a means to generate voters' attention. Televised campaign ads form a bridge between crime rhetoric and crime images. Further, the reality of crime is transfigured by the images of crime used in the ads, and this spectacle separates crime from its social context (Presdee 2000). At issue in the current project was not whether an ad was persuasive or effective per se. Rather, campaign ads were considered as sites for cultural images and narratives about crime, in which rhetorical metaphor could be rendered into visual metaphor.

Yet the presence of crime in mediated images is not enough to understand the presentation of crime (e.g., Carrabine 2012; Cecil 2010; Welsh, Fleming, and Dowler 2011). We are pushed towards a methodological perspective that embraces and politicizes the image - its representation, style, meaning, evocativeness (Hayward and Presdee 2010). Visual analysis aims to "discover significant patterns in the depicted (the 'what') and in the manner of depiction (the 'how') in order to...develop plausible interpretations that link observations to...social processes and normative structures" (Pauwels 2017:64). Following Grady (2007), the images in campaign ads are interpreted as iconic constructions, created for a purpose in their own time and place, but acquiring additional meaning as they move across contexts. Such images are linked with symbolic representations, deliberately emotive, and imbued with the actions and intentions of their political creators.

\section{Methods}

\section{Data source}

The Museum of the Moving Image (n.d.) maintains an online digital library of campaign TV ads from 1952 to 2016, The Living Room Candidate. I relied on this site for two reasons. First, Griffin et al. (2012), using 
a quantitative approach to content analysis, created a publicly available dataset based on ads posted on this website. As described in the next section, their dataset was an early starting point for the current study. Second, the website offers a non-partisan selection of ads, posts a relatively equal number from each candidate, and provides background details about each ad (e.g., airdate, producer, sponsor, transcript). Although ads may be available via other sources (e.g., YouTube), using the Living Room Candidate site removed biases that can occur in search engines' algorithms and is easily accessible to other scholars.

\section{Analytic approach}

For this project, I began with the University of Nebraska's Campaign Ads Project (Griffin et al. 2012), which was a quantitative content analysis (e.g., Benoit 2001; Franz et al. 2007) of ads from 1952-2008. In addition to their codes related to aspects of political communication, the Griffin team coded for a number of diverse features including issues, use of narration, types of emotional appeals, visual images, music, sound effects, and characteristics of people featured in the ads. The team generally coded for presence or absence of these factors, then coded within discrete categories if additional information was needed (e.g., sound effect: positive, negative, both). Among other issues, ads in the dataset were coded as containing references to crime (organized crime, gangs, lawlessness, crime fighting), illegal drugs (war on drugs, drug use), and/ or courts (court system, Supreme Court, justice). I scrutinized the detailed codes for these ads in order to develop a sense of what kinds of content crime-related ads contained.

One of the shortcomings of quantitative content analyses is that content is divorced from context (Muzzatti 2006). I was unable to determine, for example, how narration was linked to images. Moving forward with my own data collection I relied on qualitative media analysis (QMA; Altheide and Schneider 2013), developed from Altheide's (1987) ethnographic content analysis. QMA assumes meaning is present in various modalities, such as text, formatting, visual and auditory stylings, as well as in the positioning of one piece of information among others. The goal of QMA is to discover how mediated materials communicate meaning, and the emphasis is placed on gathering descriptive, conceptual, and contextual data. The procedures for data collection, analysis, and interpretation are also reflexive, with the researcher constantly engaged in 
the material: deliberating over observations as the process unfolds and accommodating conceptual or theoretical nuances (Altheide and Schneider 2013).

QMA coding protocols are oriented conceptually rather than the categorical approach taken in quantitative coding schemas. Data collection was guided by a coding rubric that passed through several stages of theoretically and empirically driven development, testing, and re-testing. In order to make initial comparisons to the Griffin et al. (2012) dataset in the early stages of data collection, I incorporated several of the same or similar categories. The final coding protocol, however, was largely openended, with categories such as storyline-images, storyline-sounds, unfolding and/or overall tone, and pacing.

Data collection proceeded as follows. I screened each of the ads paid for by the candidate or political party available on the source website through $2017 .{ }^{1}$ Of the more than 350 ads on the Living Room Candidate site, I flagged 44 as containing crime-related content (see Appendix). I would watch the ad in full and read the transcript to gain an overall impression. Because the objective was not only to see images and hear sounds, but to pair them with each other and put them in context with any narration or on-screen text, I used a reiterative process, watching the ad in segments, pausing frequently and replaying in order to code for as much detail as possible. ${ }^{2}$

The analytic process began with a conceptual map of the themes that emerged from coding and the relationships among them. Because QMA by design is immersive, during the analysis and writing process I frequently rewatched the ads to confirm observations or to view them in light of the key themes I describe below. As with any content

${ }^{1}$ Griffin et al. (2012) only coded ads paid for by the candidate's campaign or political party. I continued this. First, it allowed for initial comparisons to their data. Second, it allowed for comparisons across years, as early ads were only paid for by the campaign or the party. I also made the decision to include the infamous "Willie Horton" ad from Bush's 1988 campaign. This ad was sponsored by the National Security PAC, but I included it because of its iconic status and because it was part of the "conversation" among the ads that year.

${ }^{2}$ During the course of the project, two graduate assistants participated in screening and coding ads in order to learn about QMA. They would watch and code ads independently. Our research meetings were reflexive exercises, comparing our notes within ads, discussing themes and differences across ads and across time, often rewatching the ads together. All coding notes used for this article were my own. 
analysis, however, it is important to acknowledge the limitations posed by human coding. Other researchers may distill different themes or find unique relationships among elements within and across ads; in the future, such analyses would yield additional insight into the results detailed here. Additionally, this study cannot address how a target viewer may process the images and messages they receive. Audiences should not be viewed as passive receptacles but as negotiating, or even resisting and reconstructing, images and meanings (Enns 2016; Kappeler and Potter 2018). It was also beyond the scope of this project to untangle the webs of misdirection, misleading statistics, newspaper headlines loosely used as evidence, and falsehoods some campaigns would spin into their ads (either visually or in voice-overs). Instead, the project focused on the story about crime being crafted in the ads across time and campaigns.

\section{Analytical focus}

The overarching goals of the analysis were: (1) to reveal how the metaphor of crime was visualized in the campaign ads, and then (2) to understand how these images were positioned and manipulated alongside other contextual information. In short, how did rhetoric become visual metaphor, and to what effect? Using the data gathered for each ad via the protocol, I analyzed the visual, aural, and narrative patterns that emerged from the observations both within campaign years (for historical context) and throughout the sample. In addition to the historical trends, two broad themes were identified: crime as social problem and crime as threat. Each of these themes is explored in further detail below.

\section{Historical trends and context}

No ads with crime-related content appeared in the sample for 19521960, 1976-1984, and 2004-2012. The earliest attempt to insert crime as major issue was in two of Barry Goldwater's ads in 1964. Most of the ads containing crime content were concentrated in certain campaign years: 1968 (Nixon-Humphry- Wallace); 1972 (Nixon-McGovern); 1988 (G.H.W. Bush-Dukakis); and 1996 (Dole-W.J. Clinton). In 1992, there was 
only one G.H.W. Bush ad and one Clinton ad. One G.W. Bush ad in 2000 mentioned crime. In 2016, a few Trump campaign ads placed emphasis on crime. ${ }^{3}$

Historically, crime ads were more common during the years in which there was broader political reshaping of the American ideology of crime and punishment as a rejection of the social welfare paradigm and a reembracing of paradigms condoning harsh punishment in the name of safety (Hagan 2010; Unnever and Cullen 2010). 1968 saw the rise of the Southern Strategy, an attempt by Republicans to capture White Southern Democratic voters by exploiting their anxieties about the Civil Rights Movement and racializing crime (Beckett 1998; Mendelberg 2001). The Nixon administration ramped up the war on drugs, particularly starting with a June 1971 speech, and took that issue on the 1972 campaign trail (Johnson et al. 1996). The 1988 campaign came on the heels of Reagan's war on drugs, the final throes of the Cold War, and a climb in violent crime (Mendelberg 1997). By 1996 the overall decline in violent crime had begun but rates were still high, and conservatives continued to pursue the "values" angle of their politicking, turning crime into a moral issue (Golden 1997). Among those campaign years in which crime frequently appeared, major themes emerged. Interestingly, adherence to the theme was relatively the same within a year, regardless of candidate.

\section{8 - Order}

In the 1968 ads, order was the prominent theme. Crime, street violence, and civil unrest were deployed as the symbols of disorder. Humphrey positions himself as a law-and-order Democrat, echoed in an ad featuring Frank Sinatra stating, "He's a man who promised he would bring peace and order to our streets." In an ad featuring his convention speech, Humphrey decries "disregard for the law" as "the advanced guard of anarchy" that "must and will be stopped." History, of course, tells us about the demonstrations that turned violent at the 1968 Democratic convention; Nixon's campaign seized this opportunity. Both the

\footnotetext{
${ }^{3}$ Two H. Clinton ads also referenced crime by replaying Trump's statements connecting crime to Mexican immigrants, but the ads themselves were not centered on crime themes.

${ }^{4}$ Humphrey, 1968, "Every American".
} 
ads "Failure" and the aired-only-once "Convention" juxtapose pictures of protests with convention activities, painting conventioneers and Humphrey as comically oblivious to the events. In "Failure" images of protesters being dragged, fires, and burning buildings are paired with the narration, "How can a party that can't keep order in its own backyard hope to keep order in our fifty states?" Nixon's ads are particularly concerned with order, and uncompromisingly reacted to protests and unrest: "Let us recognize that the first civil right of every American is to be free from domestic violence [i.e., violent protests]. So I pledge to you, we shall have order in the United States." 5

The candidates' representations of order, however, differed. Humphrey's ads feature the candidate or his surrogates (Sinatra, actor E.O. Marshall) speaking or addressing the TV audience. The speakers' tones are measured. Even when there is a slight edge to the topic, such as when they talk about the opposing candidates, the speakers remain reserved. The pace is moderate, with few scene changes, usually shifting between the speaker and audience. The sound effects are limited to applause placed appropriately, and there is no music. The exception is "Mother and Child," in which a woman engaged in quiet self-reflection about violence in society is accompanied by a hummed lullaby and a hushed male voice-over advocating Humphrey's policies. Order in Humphrey's ads is calm resilience.

In stark contrast, Nixon's crime-related ads are generally frenetic and psychologically intense. "Crime," "Failure," and "The First Civil Right" each use still images shown in rapid succession, sometimes with rapid zooming in or out. These pictures are jarring: an injured (or is he dead?) young man lying in the street, a bloodied protestor, people yelling with their faces twisted in rage, fires, police tangling with groups of angry people. Some of the images are the same across ads. In "Crime" and "Convention," the camera work on the stills spins kaleidoscopically. The accompanying music throbs, with dissonant chords neatly evoking the pitch and tone of horror movies popular at the time. ${ }^{6}$ In "Convention,"

\footnotetext{
${ }^{5}$ Nixon, 1968, "The First Civil Right".

6 This observation was made by one of the graduate students familiar with these films (e.g., Night of the Living Dead). In my own notes for Nixon's "Crime," I wrote that the "subtle throbbing of music paired with the rapidity of images elicited stress in me, and I know what I'm watching!" Brookman and Copes (2018) speak to the role of the researcher's emotionality in visual criminological methods.
} 
the music takes an eerie tone, juxtaposing faux-upbeat music in the convention scenes alongside psychedelic music in the unrest scenes. The voice-over (either Nixon himself or a male narrator), when present, is forceful and ominous. The exception to these tactics was "Unite," which also uses stills in sequence, but these depict mostly White families, landscapes, and cityscapes, the score is idyllic, and Nixon's voice-over more refined. All these ads end the same: in abrupt silence with the campaign slogan and the name "Nixon" lingering on the screen. Order in these ads is Nixon himself.

\section{2 - Drugs}

In 1972, drugs - as bringer of crime and destroyer of youth - figured into the campaign ads of both Nixon and McGovern. Crime and civil unrest, in and of themselves, were largely absent as topics and motifs. Nixon's ads highlight his efforts to curtail drug trafficking ${ }^{7}$ and his opposition to marijuana decriminalization (in a jab at McGovern's earlier stance). ${ }^{8}$ His major statement about drugs appears in the four-minute "Youth" ad, in which drugs are labeled a "public enemy." The narrator describes Nixon's spending to educate youth about "how dangerous drugs are, and to rehabilitate those who got the message too late." McGovern's major statement appears in his "Crime and Drugs" ad, in which he explicitly links the two, "You're never going to get on top of crime in the United States until you get on top of drugs, because half of all the crime in this country is caused by the drug addict."

Nixon's "Youth" bears little resemblance to his 1968 ads that tackled similar issues (the Vietnam War, crime, and civil unrest). Gone is the frantic pace. Although images change, the length of the ad allows for more time to linger on lighter fare that overcome the darker images. Gone is the scary music. Instead, the music is understated, crescendoing and intensifying to match pictures of drug paraphernalia, but fading when the storyline shifts to more positive stances (e.g., funding for rehabilitation). Like the 1968 ads, they conclude on Nixon's name and the campaign slogan (this time read aloud by a male narrator), punctuating the "progress" illustrated in the ads. McGovern's ad extends Humphrey's

\footnotetext{
${ }^{7}$ Nixon, 1972, "Passport".

${ }^{8}$ Nixon, 1972, "McGovern Turnaround".
} 
tactic of speaking to audience; in this case, McGovern stands on a factory floor listening to and taking questions from male workers. The ad focuses on his answer and the nodding, knowing responses of the crowd. The pacing is conversational, there is no music, and the ad closes on a freeze-frame of the factory men surrounding McGovern with "McGovern" written overtop as the male narrator pronounced the slogan with calm resolve.

\section{8 - Violence}

Crime reappeared as a major issue in ads for the 1988 contest between Bush and Dukakis. Violence, often represented by the phrase "first-degree murder," and the associated risk was the key theme. This campaign contributed two iconic ads to the political lexicon, Bush's "Revolving Door" and “Willie Horton." If Nixon's 1968 ads were jarring for their imagery, the 1988 ads were unsettling for their direct language. In a Bush ad using the September 25, 1988 televised debate as backdrop, viewers are told with narration and on-screen text about "released killers," "49 convicted drug dealers and offenders," and "53 murderers." 9 The "Revolving Door" ad informs viewers about 286 escapees from the Massachusetts furlough program who "committed other crimes like kidnapping and rape." Both candidates' ads tell tales of violent crimes: a Massachusetts escapee who "terrorized" a couple; Horton's crimes of murder, kidnapping, and rape; a heroin dealer furloughed from federal prison who "raped and murdered" a pregnant mother; and how Dukakis's elderly father was "gagged and beaten and robbed."10

In 1968, Nixon and Humphrey vied to position themselves as the candidate that would restore order. In 1988, the question hinged on which candidate would keep people safe from violent crime. The Bush campaign made the most of Dukakis's statement in the September debate that he was "tough on violent crime." Bush's "Credibility" ad openly mocks Dukakis: a freeze-framed shot made him appear to smirk and the narrator chided, "Even Michael Dukakis can't say he's tough on crime with a straight face." All but one of the crime-related ads in 1988 was an attack on the opposing candidate. The ads were also in conversation

${ }^{9}$ G.H.W. Bush, 1988, "Credibility”.

${ }^{10}$ In order: G.H.W. Bush, 1988, “The Risk;” G.H.W. Bush, 1988, "Willie Horton;” Dukakis, 1988, "Furlough from the Truth; "Dukakis, 1988, “On Your Side”. 
with one another, in that Dukakis's ads respond to Bush's attacks. Bush paints Dukakis as a risky choice; Dukakis answers by defending his record. Whereas Humphrey presented a different view of order than did Nixon, Dukakis failed to offer an alternative narrative to Bush. Rather, the Dukakis campaign ads used similar talk of violence, even co-opting part of Bush's "Revolving Door" ad and layering in more violent anecdotes. With the thread of violence connecting the ads, the expression "tough on crime" took on visual meaning.

\section{6 - Crime writ large}

By the 1996 contest between Dole and Clinton, crime-writ-large was the primary theme, depicted by violence, drugs, hints at juvenile delinquency, and - new for 1996 - "illegal" immigrants. Topics were often muddled within the ads. For example, Dole's "Classroom" emblazons "TWO MILLION ILLEGAL ALIENS" across the screen, then describes costs to the criminal justice system, schools, and the tax burden. Again, in capital letters, the ad claims "Clinton gave citizenship to aliens with criminal records." Clinton responds in the "Signed" ad, touting how he rounded up "illegal immigrants and criminals," complete with live action video of police making arrests. The ads concerning juvenile crime also demonstrated overlapping concerns. Clinton shares plans to crack down on teens' illicit behaviors, juxtaposing these ideas with images of happy kids. Dole forcefully decries juveniles getting hooked on drugs.

The tough-on-crime posturing, present in the 1988 campaign, was also evident in the 1996 ads. Again, the candidates tried to position themselves as tough, but in 1996 they also tried to position themselves as morally equipped. What crime really signaled was a decline in American morals, and one apparently cannot be tough if he is immoral. Dole's ads promote the candidate's own "moral compass" while undercutting Clinton's moral authority, because he "never took the drug crisis seriously." 11 Several of Clinton's ads embrace the language of "protecting our values" by attacking crime. ${ }^{12}$ They routinely picture police officers to reinforce the notion of protection. In "Drums," Clinton directly confronts voters with what version of toughness/morality they want: one

\footnotetext{
${ }^{11}$ Dole, 1996, "The Story;" "Too Late".

12 Clinton, 1996, "School;" "The Facts".
} 
that opposed the Brady Bill, which Dole did, or one that enacted it, which Clinton did.

This push-pull of tough-on-crime morality harkened back to attempts by Nixon's campaign to paint Humphrey as unequipped to instill order, his attempt to show McGovern as permissive on drugs, and Bush's attempt to depict Dukakis as foolish and risky. In this case, whereas Clinton's ads largely took a positive attitude, Dole's ads were dour and stark. Black-and-white invoked contrast. Clinton's ads were typically in color, except they depicted Dole in black-and-white. Dole's attack ads targeting Clinton were also in black-and-white. Clinton's 1996 ads brushed the personal morality issue aside and co-opted the tough-on-crime narrative, touting the administration's accomplishments on crime issues and proposing a tough future, such as breaking up "violent gangs." ${ }^{13}$ The 1996 campaign, at least when it came to the heavy politicization of crime in presidential ads, continued the narrative established by Nixon's 1968 campaign and reinvigorated by the 1988 campaign. A toughon-crime position was communicated in part via scary scenarios, and in part by the symbolic show of force via law enforcement, which represents our values.

\section{Summary}

Johnston and Kaid (2002) distinguished between image ads, which focus on the candidate's character, and issue ads, which focus on topics. They argued that language in image ads is less about emotions, but instead crafted to present a portrait based on candidates' characteristics. In contrast, in issues ads language is not necessarily factual or based on data; rather it is "emotional, designed to make voters feel something, not know something" (p. 298). Over time, however, the distinction between image and issue ads has blurred. Consistent with observations, ads primarily designed to dramatize crime-related issues tended to use visual images with limited (but pointed) verbal content and placed less emphasis on the "hard sell" (Johnston and Kaid 2002: 283). Narrators particularly from the 1980s onward, tended to offer unseen commentary, voice-overs which acted to construct the characters of the candidates vis-à-vis crime.

\footnotetext{
${ }^{13}$ Clinton, "The Facts".
} 
Starting with the 1968 campaign's emphasis on order, ads presented candidates as the people with the character to instill it. Later campaigns, with their emphasis on the candidates' toughness or moral authority, further blurred the issue-image distinction, by making the candidates' characters themselves an issue entangled with crime. The shift to toughness above-all-else, and away from any notion of social welfare reforms in response to crime, violence, or drugs, began in earnest during the 1968 campaign, was brought to fruition in the 1988 campaign and has since characterized campaigns' tone about crime (Newburn and Jones 2005).

Across these campaign years in which crime figured prominently, crime arose as a specter, certainly to be feared and undoubtedly to be contained. All the while, the ads beat the drums of outrage and disdain, lamenting the loss of order, then safety, and finally morality. The next aspect of the analysis unwrapped just how crime-related content was situated in ads. Two broad tactics emerged: (1) treating crime as a social problem akin to other social ills (e.g., war), or (2) posing crime as the sinister side - and threat - to an otherwise vibrant society. These ploys, which could occur within the same ad, aligned with the rhetorical metaphors that emerged from Presidents Johnson's view of crime as both a stain and a shadow.

\section{The stain: crime as social problem}

One broad type of campaign ad situated crime as a social phenomenon akin to other social ills, such as poverty, war, government spending, the environment, and education. These social problems had been addressed (or not) by the incumbent candidate or needed to be managed by a newly elected president. What these ads shared was their tendency to have laundry lists of topics, and they did not typically linger on crime. However, the overall tone of these ads divided them. Stains, after all, must be cleaned. A candidate has either started cleaning - a light, fresh Mr. Clean feeling - or is preparing the cleanser to wipe the stain away like a janitor might - a dirty, gritty exercise. 


\section{Mr. Clean}

The majority of the laundry list ads in which the candidates themselves appear tended to position the candidates as "Mr. Clean," tackling a variety of tough stains with a refreshing air of confidence and competence. Evoking hands-on work, candidates were often pictured with their suit coats off and/or their sleeves pushed up. They also tended to be shown in friendly settings: grinning and shaking hands, leaning in and listening, riding in parades and waving to crowds. The characters in the ads were equally spic and span: smiling youth, families, older folks, and usually White. Characters were receptive to the candidates; they were warm with him and with each other. The production focused on gentler idyllic music and brighter images. Narration sounded like a play-by-play of either accomplishments or plans. For those ads that used a large number of cuts or transitions between images, the pacing of the music and narration tempered any sense of commotion. Rather, transitions acted to tick off a checklist of tasks either completed or planned for the future. As a result of this approach, crime content, in particular, was one of many issues, yet positioned as isolated from the others. Crime was not linked to social contexts, rarely if ever pictured as a consequence of racism or a porous social safety net. Crime statistics and anecdotes were positioned as evidence of accomplishments.

For example, Nixon's 1972 "Youth" touts the creation of EPA illustrated by nature scenes, then transitions to pictures of labeled drugs, as the music, imagery, and narration take an abrupt but momentarily darker tone. The music and narrator lighten again as the ad transitions to a group of young adults, seemingly at ease in a library meeting room listening to a speaker, while viewers hear about the administration's increased spending on drug education and rehabilitation. The ad then moves on to foreign policy. Similarly, Clinton's 1992 "Leaders 2" lists plan to "end welfare as we know it" followed by a scene of Clinton backed by police. The narrator confirms: "They've sent a strong signal to criminals by supporting the death penalty" paired with the on-screen text "Support the death penalty" to drive it home. The piece then shifts to taxes. In 2000, G. W. Bush's "Successful Leader" reports on his accomplishments as governor, including, among other items, reducing "junk lawsuits" and cutting "juvenile crime 38\%" with the latter point made by the narrator and on-screen text. Throughout Bush is pictured in a variety of 
settings, speaking and shaking hands. In the case of juvenile crime, he is at a juvenile reform facility talking with drill instructors, then with a high school cheer group when the text is on-screen, finally shifting to a series of closing scenes and points. Ads in this vein, by decontextualizing crime, gave the impression that crime is containable.

Yet, in some cases, there was an implicit linkage between one item on the checklist and the next. For instance, Nixon's 1968 “Unite," scored with minstrel-like music, depicts outdoor family-in nature scenes, leading into cityscapes paired with narration about leadership to "calm its angers" and "ease its terrible frictions," briefly linking urbanicity and crime before turning to a variety of "people together" settings (e.g., beach, sporting event, shopping). In Clinton's 1996 "Next Century" piece, both times crime is mentioned it is situated between family-focused segments, and the crime-related text on screen lingers as images fade to next topic. ${ }^{14}$ While the Clinton voice-over says "We are safer," a serious Clinton walks down courthouse steps with police flanking him and the text "death penalty for drug kingpins" appears on the screen. This text lingers as the image fades to a man pushing boy on a swing and the voice-over tells use "we are more secure." The second segment uses a similar technique. A three image sequence - a family going to church, Clinton at a podium with police behind him, a chalkboard being erased - rolls as the text "for the future" appears on screen, the voice-over extols the "values we embrace and the things we fight for" while text fades to "ban cop killer bullets." With ad elements like these, crime was positioned as the problem that stained other social elements, the implication being that cleaning up crime also cleanses other problems.

\section{The janitor}

A second approach to laundry list ads positioned the candidate as a janitor prepared to scrub the stain of crime and other social ills, to do the hard jobs others are not prepared to do. These ads were sterner: no smiling faces, no light-hearted interactions with crowds. Instead, the production was all business, relatively slow-paced, with few transitions between scenes. For instance, Wallace stands at a podium, with short

14 Given the faster pace of the ad, this subtly only became apparent after multiple viewings. 
visual vignettes following his talking points. In Humphrey's "Marshall," the speaker is in dark soundstage, walking among large black-and-white pictures of the candidates. Narration is still like a play-by-play of problems and plans, but the tone is somber. The imagery is generally stark, such as G. H. W. Bush's 1992 “Arkansas 2” piece that uses black-andwhite moving images of a barren landscape.

Crime is a dark stain, and these ads, in particular, teased the threat in their positioning of the crime-related content. Wallace's ad leads into the specific crime segment with the closing image of his states' rights segment: a school bus hauling White kids away into the unknown. Wallace's crime related vignette has a woman walking on a darkened sidewalk, the sound of a gunshot, a shattering street light, and subsequent darkness. Bush's 1992 ad lists the woes of the state of Arkansas, intoning that "the FBI says Arkansas had America's biggest increase in the rate of serious crime" as "Biggest Increase in Serious Crime Rate" appears against blackened clouds. In contrast, Humphrey's ad is only a forceful oration. However, Humphrey's surrogate looks the viewer in the eye and challenges the opponents' abilities to clean-up crime: Wallace because of his unpredictable "personal prejudice," and Nixon because he only offers his untrustworthy "personal assurance" that he can get "violence to disappear." The crime problem is a dirty business that only some men can clean.

\section{Someone has to clean up this mess}

When crime is treated as a metaphorical stain on society, an unclean social ill, someone has to clean it up. In these ads, rhetoric was manifested in the visual separateness and tarnish of crime to plug the candidates as courageous caretakers and leaders. When the stain of crime falls on the fabric of society, this is a candidate who can clean up the mess. The police officers in the background were reduced to props, staged as willing supporters of the cleaner-in-chief. The happy people and tranquil settings were reduced to shiny surfaces, reflecting the admirable work of the candidate.

When the dark mark of crime seems to spread, this is a candidate that can also reclaim our purity and deliver us. Blotting out crime means our communities and families will not be contaminated. By working to "get rid" of the causes of crime, "This is a time when a good man can become 
a great man."15 Wallace promises to "make it possible for you and your families to walk the streets of our cities safely." Nixon is "leadership that believes in law and has the courage to enforce it, leadership that believes in justice and is determined to promote it." Likewise, Dole offers "the principle of accountability to strengthen our criminal justice system." G. W. Bush, patting reform school students on the back, pledges "a fresh start for America." ${ }^{16}$ With the stain of crime removed, the leader can remedy other social ills.

\section{The shadow: crime as threat}

A second type of campaign ad focused solely on crime itself. These ads depicted crime as a sinister element threatening an otherwise vibrant and moral society. What these ads shared was the portrayal of crime as a threat that must be neutralized. There was a contrast, however, between ads that focused on the candidate himself (or his opponent) and ads that deliberately visualized crime. The former tended to take the shape of stump speeches, the candidate neatly positioned as a shepherd overlooking his flock. The latter fully embraced fear, despair, and moral outrage against the wolves who threaten that flock. Consequently, the ads also differed in production styles, as detailed below.

\section{The shepherd}

Both the Humphrey and McGovern campaigns aired pieces that essentially feature the candidates speaking about their intentions to guard against crime. Humphrey's "Every American" ad compiles clips from his convention speech, interspersed with conventioneers cheering his points. Others feature the candidates in unrehearsed environments. The candidate, however, is the center of attention. Humphrey answers a reporter's question from behind a podium, and McGovern stands on a factory floor surrounded by a flock of male mostly White workers. ${ }^{17}$

\footnotetext{
15 Humphrey, 1968, “E. O. Marshall”.

16 Wallace, 1968, "Bussing/Law and Order;" Nixon, 1968, "Unite;” Dole, 1996, "The Story;" G. W. Bush, 2000, "Successful Leader".

17 Humphrey, 1968, “Law and Order Democrat;” McGovern, 1972, “Crime and Drugs”.
} 
There is no music. There are no images of offenders, victims, or anything emblematic of crime, disorder, or deviance. Rather, the oration tells the viewer what is at stake. Humphrey's convention speech claims Americans have "the right...to a safe and a decent neighborhood" and that "rioting, burning, sniping, mugging, traffic in narcotics, and disregard for law" must be controlled. The narrator asks voters to give Humphrey the "authority" to reign in these problems. Yet, as the "Law and Order Democrat" ad makes clear, Humphrey does not endorse making things better by building more jails but creating "more decent neighborhoods, more educated people." McGovern also walks this line between responding to crime with social programs when responding to an audience member's criticism of Nixon's drug policy. McGovern, in his shirt and tie with his sleeves rolled up, explicitly connects crime to drug use, claiming crime is caused by drug addicts, and verbalizes the threat: "They'll kill, they'll steal, they'll do anything to get that money to sustain that drug habit. And we've got to have a program that's better..." McGovern, the narrator reads from the text written over a freeze frame of the factory scene, is "for the people."

Both candidates rhetorically invoked the threat, and positioned themselves between the people and this vague threat of rioters and druggedout killers. They remained vigilant of this threat yet cognizant of the surrounding social landscape. Both of these candidates, however, competed against Nixon campaigns that vociferously deployed visual and aural techniques. Perhaps this is one reason why this particular style of ad, relying primarily on words to invoke the crime-as-threat metaphor, fell out of favor by the 1980s and 1990s. Dukakis's “On Your Side” featured him talking directly to the audience, basically to refute Bush's attacks; violence was one of the topics. No other campaign used the speech technique to frame their position vis-à-vis crime.

The reliance solely on rhetoric was effectively replaced by ads that used visual and aural techniques to depict and define those who are threatened and those who are the threat. These appeared together in some ads, but also occupied their own ads. Compared to the crime-asstain pieces, the threat ads tended to employ images that were dark and dramatic. The pace in some ads was frantic; other ads slowly ratcheted up tension. Harsher music played in minor keys: low, pulsating, and punctuating. Occasionally, additional sound effects (e.g., sirens) disrupted scenes. Narrators, generally male, were somber, adopting a filmnoir style. 


\section{The flock}

Who is threatened? In the struggle for law and order, the regular (White) folks, their children, and their "values" were the virtuous characters. These potential victims were portrayed as innocent and seemingly helpless to defend themselves against the threat. The virtuous were interspersed in ads as examples: the kids on Wallace's bus; a picture sequence of "descent and law-abiding citizens" in Nixon's "Crime;" the working people at McGovern's factory or depicted in Clinton's "Signed;" school-aged White middle-class kids lured into drug use (Dukakis's "Noriega;" Dole's "Too Late"); and families, some with young children, others intergenerational.

The innocent could also be central characters in ads. For example, Humphrey's "Mother and Child" features a White woman cuddling a baby; the scene is gentle, yet the humming is a minor key, lending a sense of disquiet. She is anxious, "I hope he won't be afraid the way we are. There's so much violence now. I wouldn't be so scared if I felt the understood what it's all about." Dole's "Classroom" ad explicitly opines, "We are the victims," narrated over a crime scene featuring a police car, lights, and a paramedic pushing a gurney. The scene transitions to a classroom populated by White, well-coiffed, mostly male students where "our children get shortchanged."

Still another approach was to place victims in the ads. G.H.W. Bush's "Risk" features a middle-aged White Massachusetts woman complaining a furlough escapee - "a first-degree murderer" - was apprehended a few blocks from her home. The ad goes on to feature "victims' families and concerned citizens." Victims also appear via news headlines about the crime pictured on-screen: "The victims recall their night of terror/Her story/I pleaded with him not to hurt Cliff but to...kill me." In response to Bush, Dukakis's "Furlough from the Truth" depicts an actual crime scene (a distant shot of a body bag being removed by stretcher) fading into a smiling headshot of a "raped and murdered...mother of two." Trump's "Laura" spot pushes this technique, featuring a middle-aged White women whose son had been horribly murdered. She tearfully describes it in vivid detail, talking to an off-screen interviewer, interspersed with black-and-white images of her holding up a family photo. The ad closes with her holding a banner that reads "A stolen life/Murdered and set on fire by an illegal alien classmate" above her son's school picture. 
While certain kinds of people were used to illustrate innocence under threat, American "values" were anthropomorphized into a definable and tangible victim. Here the visualmetaphors of Americana played an important role: flags, picket fences, suburban neighborhoods, churches, and bucolic settings. These were juxtaposed against talk, images, or sounds of riot, violent encounters, and destruction (e.g., fire, crumbled buildings). For example, the Massachusetts woman described above is speaking to an interviewer in front of a well-kept suburban home with blue sky, trees, and white picket fence, which she describes as "a safe neighborhood." Dole's ads attempt to recapture days gone by, the mythic America of flag-waving small towns, "an America with the opportunity and values of the nation we grew up in." ${ }^{18}$ Nixon's 1968 ads take a decidedly dark direction. His crime-related ads routinely illustrate the chaotic destruction of the embattled Great American City and use few positive images of Americana. Instead, America is in ruin. The final two still images of "The First Civil Right" tell the tale: in a decimated (postriot) city street, the camera pans down to a nude torso and head of a female mannequin, then cuts to a burnt-out building with a twisted metal box in the center that reads "CHANGE". The message, underscored with harshly dissonant tones, illustrates the threats to American values from the social upheavals of the late 1960s. Crime itself becomes a character that threatens the flock.

\section{The wolves ${ }^{19}$}

Who is the threat? The people rioting, screaming at cops, shootingup with drugs, plodding through barred doors, or scattering under a police helicopter spotlight were constructed as villainous characters. They were no longer human beings, but something alien, something un-American, and something dangerous. Nixon's 1968 ads, "Crime," "Failure," and "The First Civil Right" manipulate a dizzying array of stills showing young people at protests covered in blood, seemingly spewing bile and embodying rage. For instance, as the voice-over tells us about "criminal

18 Dole, 1996, "The Story".

${ }^{19}$ Although not crime-related, both Reagan and G.W. Bush had ads depicting animal predators. Reagan's 1984 "Bear" used a large grizzly to symbolize the Soviet Union, and Bush's 2004 "Wolves" used a prowling wolfpack to symbolize foreign terrorists. 
forces that threaten their [law-abiding citizens] peace and their security," a series of images depicts an angered White young man kicking at a surrounding crowd while be wrestled away by police, followed by closeups the man's twisted face.

The infamous "Willy Horton" ad of the 1988 campaign unabashedly racialized crime. The ad itself bears none of the slickness or production quality of Nixon's ads. It is essentially a PowerPoint presentation narrated like a news report with no accompanying sound effects. However, the rhetoric of first-degree murder is tied directly to a grainy black-andwhite headshot of Horton. In the picture, Horton, who is African-American, is heavily bearded, lips parted into a grimace, chin tilted up slightly, giving the appearance he is glowering down at the viewer. As the narrator recounts the original crime, this image is replaced with another grainy black-and-white newspaper photo of a police officer escorting a handcuffed Black man through the police station. ${ }^{20}$ The man is a head taller than the police officer and looms over him. The narrator recounts "Kidnapping. Stabbing. Raping." as the words appear in succession on the screen. This first-degree murderer - and others like him - are the threat.

In the 1996 and 2016 campaigns, Hispanic immigrants are the threat. They are also othered: not only for taking jobs from U.S. workers, but for being criminals and taking resources by crowding our prisons and our schools. ${ }^{21}$ Clinton's 1996 spot situates an image of three White male construction workers at a job site between an image of a handcuffed man (visible only from torso to knees) and a live action shot from a search helicopter in the night sky. It shines a spotlight onto the desert ground, where people are scattering like insects, in an intentional selection of that visual metaphor. Dole's ad complains about "illegal aliens" while the viewer peers through a prison door at a group of Hispanic men walking in. This is followed by a black-and-white street scene in which a "gang" (stereotyped males in hoodies, flannel shirts) struts briskly behind an unassuming older White man. The next scene, also black-andwhite, is a classroom headed by a White female teacher but populated with what appears to be Latino teenagers, implying they are those same

20 The man looks similar to the first Horton picture, but not exactly like him. The implication is that the man is Horton, but the ad never explicitly ties Horton's name to the news photo.

${ }^{21}$ Clinton, 1996, "Signed;" Dole, 1996, "Classroom”. 
gang members. Trump's 2016 campaign picked up this theme in the "Two Americas Immigration" ad in which "... dangerous criminals [are] kept out. The border secured." His "Laura" ad also reminds viewers that the "illegal alien" that murdered her son "should not have been here" and that H. Clinton's border policy would "allow people into the country just like the one that murdered my son." These immigrants - and others like them - are the threat.

Just as American values were anthropomorphized into victims, the threat posed by the legion of villains was made into shadow itself. Ads quite literally used darkened, blurred, or shadowy figures to insinuate criminality. For examples, Goldwater's "Moral Responsibility" opens with a church, an icon of morality, but jumps from one staged gritty street fight among "gangs" to another grainier, darker, larger rumble in which fighters are essentially faceless. Goldwater narrates: "Is moral responsibility out of style? Our papers and our newsreels and yes, our own observations tell us that immorality surrounds us as never before." With its horror movie-style score spiraling down a chromatic scale, a cop in Nixon's "Crime" appears to be cornered, the shadow of his assailant (whose outstretched arm is visible) rises behind him. A beginning scene in Clinton's 1996 "Signed" ad depicts sunset on a ridge, summited by four shadow people (presumably immigrants) holding hands, helping each other walk as militaristic music plays in the background. Bush's 1988 "Revolving Door," shot in black-and-white, places a prison and its heavily armed guards as shadow figures in order to focus on the zombie-like inmates walking in, around, and through the door. The inmates make no eye contact with each other, staring blankly as they shuffle along, while dissonant low chords drone and the narrator whispers urgently how "many are still at large."

Drug users, drug dealers, and drugs themselves shared the same shadow quality. Exploiting the famous Johnson "Daisy Girl" ad about nuclear war, Dole decries, “Today the threat is drugs." ${ }^{22}$ Nixon's 1972 "Youth" offered close-up shots of labeled drugs and drug paraphernalia laid out on sterile tables, while the darker music and narrator reminds the viewer that Nixon labeled drugs "American's Public Enemy Number One." Similarly, Dukakis's “1982 Noriega” uses snapshots of cocaine bricks piled up and labeled "Horda" (literally: horde or gang) to

22 Dole, 1996, "The Threat". 
illustrate increases in cocaine trafficking and "more drugs in our classrooms." Drug users are reduced to limbs and torsos: close-ups of arms being injected, hands preparing or trading drugs and money. Drug dealers and traffickers are strawmen - never pictured, with the exception of Panamanian leader Manuel Noriega. Like the ads featuring criminals, ads in which drugs figured typically removed drugs from social context and erased human identity.

\section{Wolves in sheep's clothing}

Nowhere was the incongruence of victim and criminal more vividly portrayed than with youth (see Sherr 1999). Children and teens were positively depicted throughout the campaigns in family, school, or social settings, metaphorical stand-ins for innocence, purity, and hope. Young people may represent the future, but some of them were not in the future imagined by campaigns. They may be civic participants, but they were also rebellious protestors. They may be innocent targets, but they were also violent super predators.

Goldwater's “Morality” exclaims “JUVENILE DELINQUENCY!” in jagged white letters, sandwiched between images of a group of White teens laughing and shouting (perhaps at a concert) and a stream of handcuffed people with coats pulled over faces being marched two-by-two through a heavy door; drilling music plays in the background. From his living room, he calls for this generation to "set a standard of responsibility." Nixon's 1968 ads exploit the youthfulness of protests that turned disorderly and violent, noting that nothing "justifies turning to violence," while his 1972 ad patronizingly commends young people who protest the correct way by walking in orderly lines with peaceful messages in broad daylight. ${ }^{23}$

School-aged White middle-class kids are lured into drug use, but they become the addicts that trouble the nation. Dukakis claims Bush's failures to control drug trafficking led to "more drugs in our classrooms" as a series of stills show two clean-cut White teenage males, sitting on indoor steps with folders and books sitting between them. ${ }^{24}$ As the camera zooms in, it focuses on a line of cocaine on the folder and a boy holding a straw preparing to snort. Just as Nixon's 1972 "Youth" points out, these students received the message too late, and now we must pay for it.

\footnotetext{
${ }^{23}$ Nixon, 1968, "The First Civil Right;" 1972, "Youth".

${ }^{24}$ Dukakis, “1982 Noriega”.
} 
Dole's ads draw a contrast between innocent youthful victims of bad examples and teens' decline into brazen drug use. "Too Late" begins with a clip of Clinton's infamous MTV appearance and teens chuckling, informs viewers with the news headline "TEEN DRUG CRISIS" and accompanying statistics. ${ }^{25}$ It closes with a light-voiced, sympathetic-sounding female narrator, "For the thousands of young Americans who became hooked on drugs under Clinton, his apology is too little, too late." Accompanying that narration is a black-and-white shot of a young person standing behind the building, who turns to the camera with pipe and lighter in hand, surprised as if he has been caught. In contrast, "The Threat" attempts to illustrate the plodding descent of drug users: the "daisy girl" is followed by a black-and-white shot of a male student in a school hall, dropping his books as he falls to the ground covering his face with his hands. The same news headline scrolls across the screen. Unlike the other Dole spot, the female narrator's tone is gravelly and grim. A series of images show people exchanging and using drugs, but includes a close-up picture of a person smoking a pipe near an outdoor basketball game where other people of the same age are playing. Although the ad ends with the same young person turning to face the camera, in this shot he is glaring at the camera.

In fact, at the height of the super predator era (Kappeler and Potter 2018), both Dole's and Clinton's ads made use of images of students in a variety of settings: schools, homes, playgrounds, and other community locales. While Dole's ads tended to "split" the flock from the wolves, Clinton's spots tended to overlay positive images of kids and gentler music with narration and scenery that implied something darker. For example, "School" opens with the aftermath of a car wreck in blue wash with lights flashing as the tempered female narrator tells us that "2000 kids die in drunk driving accidents." Clinton, on the White House portico, we are told, wants to "protect our kids." As splashed on the screen and read by the narrator, his plan includes taking away license of teens who drive drunk and drug testing them before getting a license, yet the image is of happy teens walking on campus. Smiling and uniformed preteens walk on school grounds, happy it seems because Clinton wants "curfews and school uniforms to instill discipline." Kids watching TV alone in a living room (in contrast with the TV program portraying a nuclear

25 During this forum, Clinton claimed that he had tried marijuana but did not inhale and did not like it. 
family playing outside) will have "ratings for TV violence." White teen girls smile up at a teacher, because "teen mothers stay in school or lose welfare." In fact, the only protection kids actually receive in this ad is from shutting child pornographers in jail. Otherwise, Clinton is apparently protecting kids by being tough on them and regulating their behavior. We might be protecting them from themselves, but the context of ads in this vein is really about protecting us from them.

\section{Who will stand for us?}

Wolves lurk in the dark, stalking the flock. We know who is lurking - inhumans, Black first-degree murderers, Hispanic illegal immigrants, juveniles - predators at once fear-inducing and frustrating. In these ads, rhetoric about the threat of crime became a visual metaphor representing them, embodying social anxieties, fears, and frustrations. They are used by campaigns as a foil for candidates' noble heroics and their opponents' ineptitudes. Between these wolves and us, candidates stand as guardians but more importantly as hunters, sheriffs, and wardens. Law enforcement officers of various stripes (e.g., police, border control, corrections), rather than being staged as background props, are more active in these ads. They are depicted patrolling, arresting, investigating, and closing prison doors, enacting the role of deputy sheriffs who exact the candidate's mission. The face of the arrestees or prisoners are distorted or cropped out of the image all together; occasionally, so too are the deputies' faces. The emphasis is on the act of subduing the wolves.

The soon-to-be-new sheriff in town "has the courage to stand up for America." We certainly "can't afford" the "risk" presented by his opponent, who does not have the fiber to chase down and contain the wolves. If the opponent wins, "we lose." Instead, the sheriff must "take the offensive against the criminal forces that threaten" safety and security. He is "protecting our values." By taking a stand against the wolves, the sheriff will "make America safe again."26

And what can we do? Rally behind the sheriff with our votes. Goldwater implores us, "[I]t is time to put conscience back in government. And

${ }^{26}$ In order of quotations: Wallace, 1968, Busing/Law and Order;" Bush, 1988, "The Risk;" Bush, 1992, “Arkansas 2;" Dole, 1996, "Classroom;" Nixon, 1968, "Crime;" Clinton, 1996, "The Facts;" Trump, 2016, "Two Americas Immigration". 
by good example, put it back in all walks of American life," while the narrator reminds us, "In your heart, you know he's right." We should go with our "gut feeling." (In this McGovern ad, after the voting lever is pulled, the narrator reassures the voter, "That's the way.") We must "TAKE A STAND." In fact, we should "VOTE LIKE YOUR WHOLE WORLD DEPENDED ON IT." 27 Our votes can foil a shadowy threat bent on upending our values and our very lives.

\section{Discussion}

Campaigns, across and within ads, blended aspects of stain and shadow en route to promoting their candidates' brands as cleaners and sheriffs. To achieve the former, crime was positioned as a social problem, decontextualized from its social origins yet implicitly linked to other social ills. Crime itself was a contaminant. To achieve the latter, the ads othered would-be criminals, anthropomorphized values into victims, and erased human identities. Disembodied shadows were refitted to embody frustration, anxiety, and threat. Across ads, music and sound, especially when paired with image or text, played an important role in setting and communicating the emotional tone of the appeal (Brader 2005), sharpening the visual metaphors of stain and shadow. In the ads, the crime metaphors had their own soundtracks, cuing viewers' sense of disdain or disgust at the stain, and their sense of fear or anger at the shadow.

Onto the messy and murky fields dramatized in these ads stepped the candidates. As Mr. Cleans or janitors, they offered to reclaim main streets and city blocks from the stain. As shepherds and sheriffs, they promised to protect us from the shadow. This is somewhat of a revision of Simon's (2001) interpretation of Johnson's metaphorical war on crime, which partnered the spreading stain with protection and the lurking shadow with reclamation. In campaign ads, the visualization of the metaphors and their transfiguration as adversaries of the candidates required a partnering that harkened to culturally relevant storylines. That is, we expect politicians to clean-up our streets, but we also expect sheriffs to stare down the villains. Moreover, given that the stain-focused ads

27 In order of quotations: Goldwater, 1964, "Moral Responsibility;” McGovern, 1972, "Voting Booth;" Dole, 1996, "The Story;" Nixon, 1968, campaign slogan. 
teased the threat, as well as the general overlapping of crime metaphors within and across ads, candidates were positioned to fulfill the role of janitor and the role of sheriff.

While justice policy steadily marched toward "toughness," the ads, with the exception of Humphrey's pieces, waved the same banner albeit in different ways. Ads were extensions of the rhetorical crime control theater of politicians (Griffin and Miller 2008), literally dramatizing crime and control, drawing on American mythos. Ads generated the appearance or promise of crime control - in language, cinematography, staging, and sound - in order to promote the competence of and confidence in the candidates. Crime may be a "real-world" problem, but the ads exploited crime like a mascot, embodying a storyline of discord overcome by hard work and vigilance (Patterson, Khogeer, and Hodgson 2013), communicating the toughened moral character of a candidate or the superiority of a policy position (Cayla 2013; Scammell 2015). The visualization and manipulation of the crime metaphor was a brand tool: evoking emotion, securing loyalty, and encouraging people to applaud with their votes.

\section{Conclusion}

The overarching goal of the investigation was to reveal how presidential campaign ads visualized the crime metaphors employed in political rhetoric. The analysis established that the visualized crime metaphor has taken different forms in different eras, rising to prominence as was suitable to the politics of the time. There were many years in which crime rhetoric was not used in the sampled campaign ads at all, suggesting that the specter of crime is resurrected when deemed expedient or necessary to craft a campaign narrative and a candidate's brand. In other words, the use of crime in campaign ads was only sometimes reactionary to real-world changes in crime, and may be more responsive to what Tonry (2009) described as a cyclical paranoia in American politics when it comes to crime. As Dukakis's campaign manager Susan Estrich reflected, "The best that can be said about political debate about crime in America is that it has nothing to do with crime. Politically speaking, crime is a values issue; the value is toughness" (cited in Newburn and Jones 2005: 77). 
The paranoid style of American politics and distrust of American government incentivizes the declaration of collective jeopardy in political campaigns (Green 2009; Tonry 2009; Zimring and Johnson 2006). The depiction of crime in campaign ads ratcheted up the salience of crime issues, exploiting the existing disdain for and fear of criminal others (Unnever and Cullen 2010). Such tactics were largely non-partisan (Chevigny 2003). Campaigns of both parties relied on the visualization of crime metaphors, particularly to construct the brand of the candidate and secure voter loyalty. In these ads, the visual and aural manifestations of crime and criminals conjured politicians' repackaged claims of crisis (Green 2009) and racialized code switches (Tonry 2009). Animus of the other was justified, toughness of the candidate was lionized, and permission was given to the flock to jeer criminals and cheer politicians.

Civil unrest, crime, violence, and drug use are complicated social problems; fear, frustration, and outrage are complicated emotions. Like campaign trail rhetoric, ads designed visual metaphors with intentionality in order to communicate social complexities simply (Kendall-Taylor and Haydon 2014). Perhaps more powerfully than rhetoric, however, visual metaphors exploited the emotional discomfort of the stain and the shadow and took advantage of existing cultural models with which the public is familiar (Ramirez 2013). Although there are variety of ways in which politics intersects with public opinion (Frost 2010), the rhetoric and imagery of campaign ads played on core American values - the hard work of the janitors, the innocent purity of the flock, the individual responsibility of the wolves, the rugged individualism of the sheriffs - visually manipulating representations of crime in the hope of political gain, while reinforcing the cultural storyline about crime.

Acknowledgments - An earlier version of this paper was presented the 2016 annual meeting of the American Society of Criminology. The author would like to thank Dr. Brandon Bosch for feedback and insight during the project, and Benjamin Forthun and Zach Thorpe for their assistance.

Disclosure - The author has no known conflicts of interest.

\section{The author}

Lisa A. Kort-Butler is an Associate Professor of Sociology at the University of Nebraska - Lincoln. Her research examines media representations of crime and justice and their implications for public opinion. She also studies physical, mental, and behavioral health among adolescents and young adults. 


\section{References}

Altheide, David L. 1987. "Ethnographic Content Analysis." Qualitative Sociology 10:65-77. doi: 10.1007/BF00988269

Altheide, David L. and Christopher J. Schneider. 2013. Qualitative Media Analysis. 2nd ed. Los Angeles: Sage.

Barnhurst, Kevin G. and Kelly Quinn. 2012. "Political Visions: Visual Studies in Political Communication." Pp. 276-91 in The SAGE Handbook of Political Communication, edited by H. A. Semetko and M. Scammell. Thousand Oaks, CA: Sage,

Beckett, Katherine. 1998. Making Crime Pay: Law and Order in Contemporary American Politics. Oxford: Oxford University Press.

Benoit, William L. 2001. "The Functional Approach to Presidential Television Spots: Acclaiming, Attacking, Defending 1952-2000." Communication Studies 52:109-26. doi: 10.1080/10510970109388546

Brader, Ted. 2005. "Striking a Responsive Chord: How Political Ads Motivate and Persuade Voters by Appealing to Emotions." American Journal of Political Science 49:388-405. doi: 10.1111/ajps.2005.49.issue-2

Brookman, Fiona and Heath Copes. 2018. "Visualizing Crime and Deviance: Editors Introduction.” Deviant Behavior 39:417-20. doi: 10.1080/01639625.2017.1407094

Brown, Elizabeth K. 2012. "Rethinking Public Opinion in Penal Policymaking: Recommendations for Research." Sociology Compass 6:601-13. doi: 10.1111/j.1751-9020.2012.00481.x

Carrabine, Eamonn. 2012. "Just Images: Aesthetics, Ethics, and Visual Criminology." British Journal of Criminology 52:463-89. doi: 10.1093/bjc/azr089

Cavender, Gray. 2004. "Media and Crime Policy: A Reconsideration of David Garland's the Culture of Control." Punishment and Society 6:335-48. doi: $10.1177 / 1462474504043636$

Cayla, Julien. 2013. "Brand Mascots as Organizational Totems." Journal of Marketing Management 29:86-104. doi: 10.1080/0267257X.2012.759991

Cecil, Dawn K. 2010. "Televised Images of Jail: Lessons in Controlling the Unruly." Sociology of Crime, Law, and Deviance 14:67-88.

Cerulo, Karen A. 2016. "Cognition and Cultural Sociology: The inside and outside of Thought." Pp. 116-30 in The Sage Handbook of Cultural Sociology, edited by D. Inglis and A. Almila. Los Angeles: Sage,

Chevigny, Paul. 2003. "The Populism of Fear: Politics of Crime in the Americas." Punishment and Society 5:77-96. doi: 10.1177/1462474503005001293

Enns, Peter K. 2016. Incarceration Nation. New York: Cambridge University Press.

Franz, Michale M., Paul B. Freedman, Kenneth M. Goldstein, and Travis N. Ridout. 2007. Campaign Advertising and American Democracy. Philadelphia: Temple University Press. 
Frost, Natasha A. 2010. "Beyond Public Opinion Polls: Punitive Public Sentiment and Criminal Justice Policy." Sociology Compass 4:156-68. doi: 10.1111/j.1751-9020.2009.00269.x

Golden, James L. 1997. "The Issue of Character in the Presidential Contest of 1996." The American Behavioral Scientist 40:994-1000. doi: 10.1177/0002764297040008004

Grady, John. 2007. "Visual Sociology.” Pp. 63-70 in 21st Century Sociology: A Reference Handbook, Vol. 2, edited by C. D. Bryant and D. L. Peck. Thousand Oaks, CA: Sage,

Green, David A. 2009. "Feeding Wolves: Punitiveness and Culture." European Journal of Criminology 66:517-36. doi: 10.1177/1477370809341227

Griffin, Dana, Damien S. Pfister, Marty Nader, and Jessy J. Ohl. 2012. "University of Nebraska Campaign Ads Project Dataset." Retrieved February 3, 2014 (https:// www.unl.edu/unecap/).

Griffin, Timothy and Monica K. Miller. 2008. "Child Abduction, AMBER Alert, and Crime Control Theater." Criminal Justice Review 33:159-76. doi: 10.1177/0734016808316778

Hagan, John. 2010. Who are the Criminals? the Politics of Crime Policy from the Age of Roosevelt to the Age of Reagan. Princeton, NJ: Princeton University Press.

Hayward, Keith J. and Mike Presdee, eds. 2010. Framing Crime: Cultural Criminology and the Image. New York: Routledge.

Huber, Gregory A. and Kevin Arceneaux. 2007. "Identifying the Persuasive Effects of Presidential Advertising." American Journal of Political Science 51:957-77. doi: 10.1111/j.1540-5907.2007.00291.x

Jacobs, David and Ronald Helms. 2001. "Toward a Political Sociology of Punishment: Politics and Changes in the Incarcerated Population." Social Science Research 30:171-94. doi: 10.1006/ssre.2000.0686

Johnson, Thomas, Wayne Wanta, Timothy Boudreau, Janet Blank-Libra, Killian Schaffer, and Sally Turner. 1996. "Influence Dealers: A Path Analysis Model of Agenda Building during Richard Nixon's War of Drugs." Journalism and Mass Communication Quarterly 73:181-94. doi: 10.1177/107769909607300116

Johnston, Anne and Lynda Lee Kaid. 2002. "Image Ads and Issue Ads in US Presidential Advertising: Using Videostyle to Explore Stylistic Differences in Televised Political Ads from 1952 to 2000." Journal of Communication 52:281300. doi: 10.1111/j.1460-2466.2002.tb02545.x

Jones, Trevor and Tim Newburn. 2006. “Three Strikes and You're Out: Exploring Symbol and Substance in American and British Crime Control Policies." British Journal of Criminology 46:781-802. doi: 10.1093/bjc/azl007

Kaid, Lynda Lee. 1997. "Effects of the Television Spots on Images of Dole and Clinton." The American Behavioral Scientist 40:1085-94. doi: 10.1177/0002764297040008009

Kaid, Lynda Lee. 2004. "Political Advertising." Pp. 155-202 in Handbook of Political Communication Research, edited by L. L. Kaid. Mahwah, NJ: Lawrence Erlbaum Associates, 
Kappeler, Victor E. and Gary W. Potter. 2018. The Mythology of Crime and Criminal Justice, 5 th ed. Long Grove, Il: Waveland Press

Kendall-Taylor, Nathaniel and Abigail Haydon. 2014. "Space to Think: Using Metaphor to Expand Public Thinking about Criminal Justice Reform." Studies in Media and Communication 2:13-23.

Lyons, William and Stuart Scheingold. 2000. "The Politics of Crime and Punishment." Pp. 103-49 in The Nature of Crime: Continuity and Change, Criminal Justice 2000, Vol. 1, edited by G. LaFree. Washington, D.C.: United States Department of Justice,

Marion, Nancy E. 1994. "Symbolism and Federal Crime Control Legislation, 1960-1990." Journal of Crime and Justice 17:69-91. doi:10.1080/07356 48X.1994.9721515.

Marion, Nancy E. and Rick Farmer. 2003. "Crime Control in the 2000 Presidential Election: A Symbolic Issue." American Journal of Criminal Justice 27:129-44. doi: 10.1007/BF02885690

Marion, Nancy E. and William M. Oliver. 2013. "Going Symbolic: Presidential Use of Symbolic Rhetoric in Crime Control Policy." Criminal Justice Policy Review 24:71634. doi: $10.1177 / 0887403412461502$

Mendelberg, Tali. 1997. "Executing Hortons: Racial Crime in the 1988 Presidential Campaign.” The Public Opinion Quarterly 61:134-157. doi:10.1086/297790.

Mendelberg, Tali. 2001. The Race Card: Campaign Strategy, Implicit Messages, and the Norm of Equality. Princeton, NJ: Princeton University Press.

Museum of the Moving Image. n.d. "The Living Room Candidate." Retrieved January 10, 2017 (http://www.livingroomcandidate.org/).

Muzzatti, Stephen L. 2006. "Cultural Criminology: ADecade and Counting of Criminological Chaos." Pp. 63-81 in Advancing Critical Criminology: Theory and Application, edited by W. S.DeKeserdy and B. Perry. Lanham,MD: Lexington,

Nielsen, Sigge Winther. 2017. "On Political Brands: A Systematic Review of the Literature." Journal of Political Marketing 16:118-46. doi: 10.1080/15377857.2014.959694

Newburn, Tim, and Trevor Jones. 2005. Symbolic Politics and Penal Populism: The Long Shadow of Willie Horton. Crime, Media, Culture 1:72-87.

Patterson, Anthony, Yusra Khogeer, and Julia Hodgson. 2013. "How to Create an Influential Anthropomorphic Mascot: Literary Musings on Marketing, MakeBelieve, and Meerkats." Journal of Marketing Management 29:69-85. doi: 10.1080/0267257X.2012.759992

Pauwels, Luc. 2017. "Key Methods of Visual Criminology: An Overview of Different Approaches and Their Affordances." Pp. 62-73 in Routledge International Handbook of Visual Criminology, edited by M. Brown and E. Carrabine. New York: Routledge,

Petrocik, John R., William L. Benoit, and Glenn J. Hansen. 2003. "Issue Ownership and Presidential Campaigning, 1952-2000." Political Science Quarterly 118:599626. doi: 10.1002/j.1538-165X.2003.tb00407.x

Presdee, Mike. 2000. Cultural Criminology and the Carnival of Crime. London, U.K.: Routledge. 
Rafter, Nicole. 2014. "Introduction to Special Issue on Visual Culture and the Iconography of Crime and Punishment." Theoretical Criminology 18:127-33. doi: 10.1177/1362480613510547

Ramirez, Mark. 2013. "Punitive Sentiment." Criminology 51:329-64. doi: 10.1111/1745-9125.12007

Scammell, Margaret. 2015. "Politics and Image: The Conceptual Value of Branding." Journal of Political Marketing 14:7-18. doi: 10.1080/15377857.2014.990829

Sherr, Susan A. 1999. "Scenes from the Political Playground: An Analysis of the Symbolic Use of Children in Presidential Campaign Advertising." Political Communication 16:45-59. doi: 10.1080/105846099198767

Simon, Jonathan. 2001. "Governing through Crime Metaphors." Brooklyn Law Review 67:1035-70.

Simon, Jonathan. 2007. Governing through Crime: How the War on Crime Transformed American Democracy and Created a Culture of Fear. Oxford: Oxford University Press.

Surette, Ray. 2015. Media, Crime, and Criminal Justice: Images, Realities, and Policies. 5th ed. Stamford, CT: Cengage.

Thibodeau, Paul H., Latoya Crow, J. Stephen, and S. J. Fluberg. 2017. "The Metaphor Police: A Case Study of the Role of Metaphor in Explanation." Psychonomic Bulletin and Review 24:1375-86. doi: 10.3758/s13423-016-1192-5

Thibodeau, Paul H. and Lera Boroditsky. 2011. "Metaphors We Think With: The Role of Metaphor in Reasoning." PLoS ONE 6:e16782. doi:10.1371/journal. pone.0016782.

Tonry, Michael. 2009. "Explanations of American Punishment Policies: A National History.” Punishment and Society 11:377-94. doi: 10.1177/1462474509334609

Unnever, James D. and Francis T. Cullen. 2010. “The Social Sources of Americans' Punitiveness: A Test of Three Competing Models." Criminology 48:99-129. doi: 10.1111/j.1745-9125.2010.00181.x

Welsh, A., T. Fleming, and K. Dowler. 2011. "Constructing Crime and Justice on Film: Meaning and Message in Cinema." Contemporary Justice Review 14:457-76. doi: 10.1080/10282580.2011.616376

Yelderman, Logan A., Monica K. Miller, Shelby Forsyth, and Lorie Sicafuse. 2018. "Understanding Crime Control Theater: Do Sample Type, Gender, and Emotions Relate to Support for Crime Control Theater Policies?" Criminal Justice Review 43:147-73. doi: 10.1177/0734016817710695

Zimring, Frank E. and David T. Johnson. 2006. "Public Opinion and the Governance of Punishment in Democratic Political Systems." The Annals of the American Academy of Political and Social Science 605:265-80. doi: 10.1177/ 0002716205285949 


\section{Appendix}

\begin{tabular}{|c|c|c|}
\hline Year & Candidate & Ad Title \\
\hline \multirow[t]{2}{*}{1964} & \multirow[t]{2}{*}{ Barry Goldwater (R) } & Morality \\
\hline & & Moral Responsibly \\
\hline \multirow[t]{11}{*}{1968} & \multirow[t]{5}{*}{ Hubert Humphrey (D) } & Every American \\
\hline & & Law and Order Democrat \\
\hline & & Frank Sinatra \\
\hline & & Mother and Child \\
\hline & & E. G. Marshall \\
\hline & \multirow{5}{*}{ Richard Nixon (R) } & The First Civil Right \\
\hline & & Convention \\
\hline & & Failure \\
\hline & & Unite \\
\hline & & Crime \\
\hline & George Wallace (I) & Busing/Law and Order \\
\hline \multirow[t]{5}{*}{1972} & \multirow[t]{2}{*}{ George McGovern (D) } & Crime and Drugs \\
\hline & & Voting Booth \\
\hline & \multirow{3}{*}{ Richard Nixon (R) } & Passport \\
\hline & & McGovern Turnaround \\
\hline & & Youth \\
\hline \multirow[t]{7}{*}{1988} & \multirow[t]{3}{*}{ Michael Dukakis (D) } & Furlough from the Truth \\
\hline & & On Your Side \\
\hline & & 1982 Noriega \\
\hline & \multirow[t]{4}{*}{ George H. W. Bush (R) } & Credibility \\
\hline & & Revolving Door \\
\hline & & The Risk \\
\hline & & Willie Horton \\
\hline \multirow[t]{2}{*}{1992} & William Clinton (D) & Leaders 2 \\
\hline & George H. W. Bush (R) & Arkansas 2 \\
\hline \multirow[t]{10}{*}{1996} & \multirow[t]{6}{*}{ William Clinton (D) } & Next Century \\
\hline & & Signed \\
\hline & & Drums \\
\hline & & First Time \\
\hline & & The Facts \\
\hline & & School \\
\hline & \multirow[t]{4}{*}{ Robert Dole (R) } & The Story \\
\hline & & Classroom \\
\hline & & Too Late \\
\hline & & The Threat \\
\hline 2000 & George W. Bush (R) & Successful Leader \\
\hline \multirow[t]{6}{*}{2016} & \multirow[t]{2}{*}{ Hillary Clinton (D) } & Role Models \\
\hline & & We Are American \\
\hline & \multirow{4}{*}{ Donald Trump (R) } & Two Americas: Immigration \\
\hline & & Laura \\
\hline & & Choice \\
\hline & & United \\
\hline
\end{tabular}

